Pacific Northwest

National Laboratory

Operated by Battelle for the

U.S. Department of Energy

\title{
Preliminary Assessment of Supplemental Grout and Glass Waste Forms for Disposal of Low-Activity Waste
}

\author{
T. Brouns \\ M. Lerchen \\ G. B. Mellinger \\ L. M. Bagaasen
}

May 2003

Prepared for the U.S. Department of Energy under Contract DE-AC06-76RL01830 


\title{
DISCLAIMER
}

This report was prepared as an account of work sponsored by an agency of the United States Government. Neither the United States Government nor any agency thereof, nor Battelle Memorial Institute, nor any of their employees, makes any warranty, express or implied, or assumes any legal liability or responsibility for the accuracy, completeness, or usefulness of any information, apparatus, product, or process disclosed, or represents that its use would not infringe privately owned rights. Reference herein to any specific commercial product, process, or service by trade name, trademark, manufacturer, or otherwise does not necessarily constitute or imply its endorsement, recommendation, or favoring by the United States Government or any agency thereof, or Battelle Memorial Institute. The views and opinions of authors expressed herein do not necessarily state or reflect those of the United States Government or any agency thereof.

\author{
PACIFIC NORTHWEST NATIONAL LABORATORY \\ operated by \\ BATTELLE \\ for the \\ UNITED STATES DEPARTMENT OF ENERGY \\ under Contract DE-AC06-76RL01830
}

Printed in the United States of America

This document was printed on recycled paper. 
PNNL-14280

\section{Preliminary Assessment of Supplemental Grout and Glass Waste Forms for Disposal of Low-Activity Waste}

T. M. Brouns

M. E. Lerchen

G. B. Mellinger

L. M. Bagaasen

May 2003

Prepared for

the U.S. Department of Energy

under Contract DE-AC06-76RL01830

Pacific Northwest National Laboratory

Richland, Washington 99352 


\section{Acronyms}

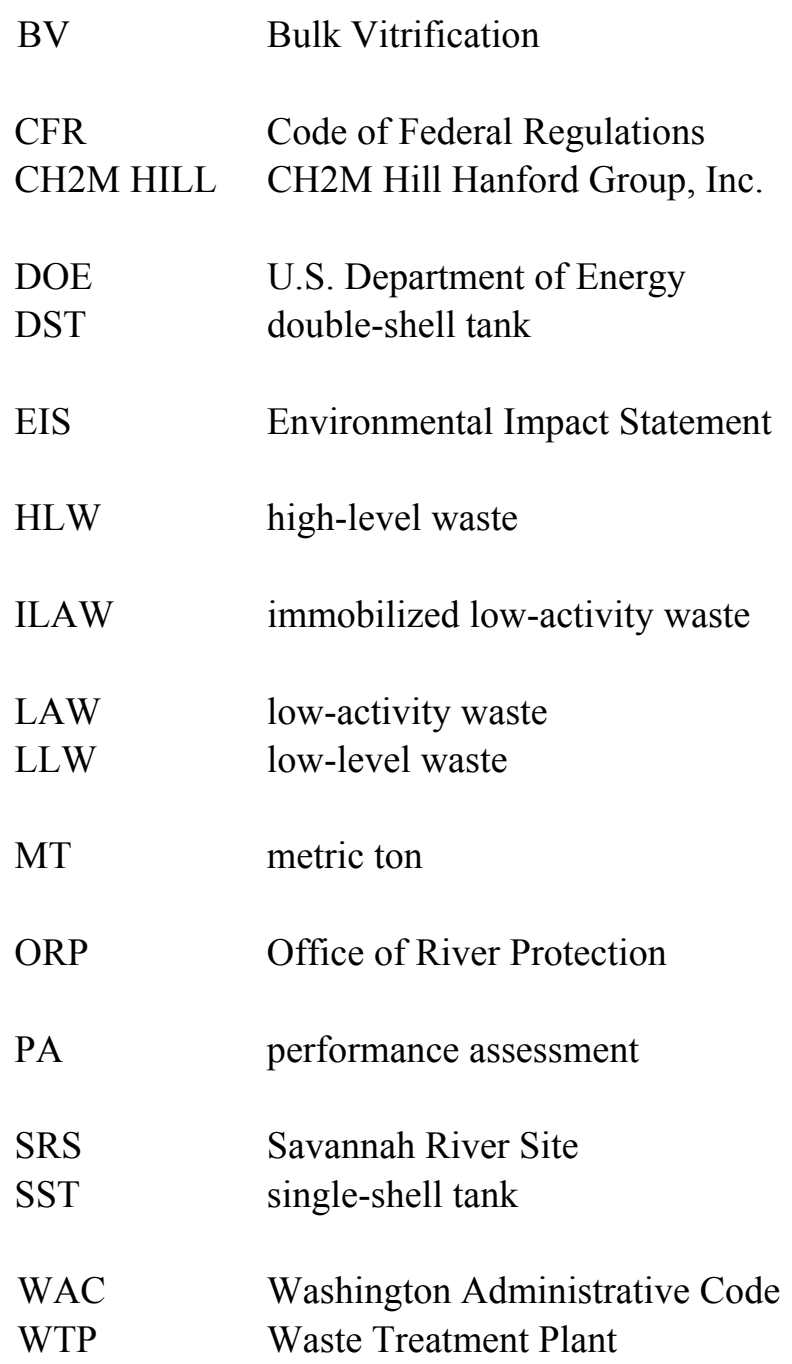




\section{Contents}

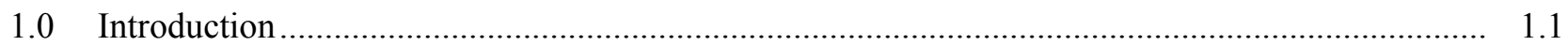

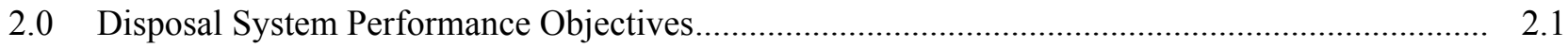

3.0 Initial Performance Assessment Results .................................................................. 3.1

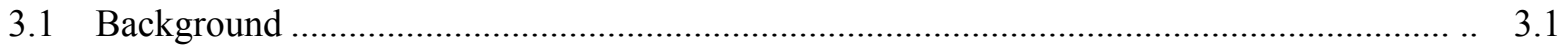

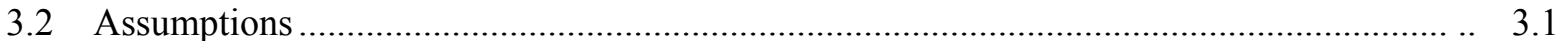

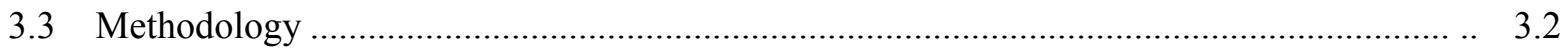

3.4 Waste Form Release Rates ...................................................................................... .. 3.5

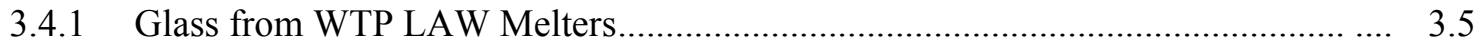

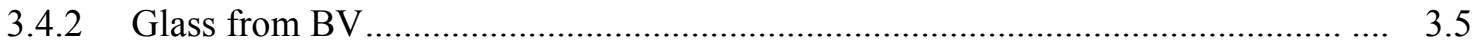

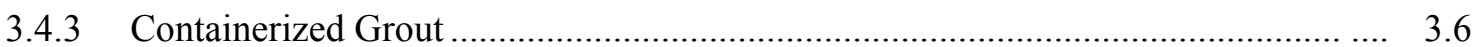

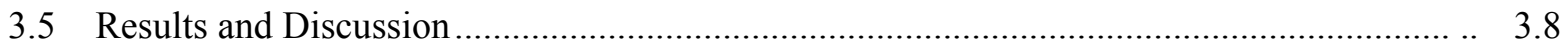

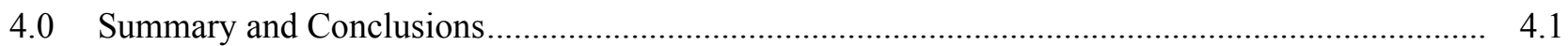

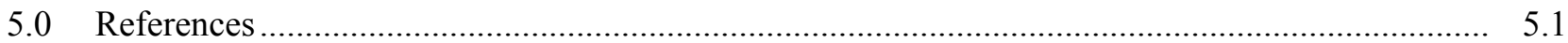




\section{Figure}

3.1 Results of Monte Carlo Analysis of Tc Release from the All-Grout Scenario at 10,000 Years

\section{Tables}

1.1 Immobilized LAW Cases Evaluated....

1.2

2.1 Disposal System Key Performance Objectives and Performance Assessment Requirements.........

3.1 Estimated Release Rate Limits for Key Contaminants to Achieve Radiological Dose and Groundwater Resource Protection Performance Objectives ..................................................... 3.3

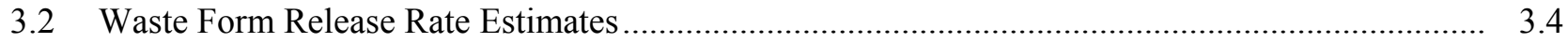

3.3 Estimated Total Effective Release Rates for Key Contaminants (most probable case)................. 3.9

3.4 Estimated Total Effective Release Rates for Key Contaminants (high-range case) ...................... 3.10

3.5 Estimated Total Effective Release Rates for Key Contaminants (low-range case) ...................... 3.11

4.1 Summary of Treatment Requirements ................................................................................. 


\subsection{Introduction}

In 2002, the U.S. Department of Energy (DOE) documented a plan for accelerating cleanup of the Hanford Site, located in southeastern Washington State, by at least 35 years (DOE 2002). A key element of the accelerated cleanup plan was a strategic initiative for acceleration of the tank waste program and completion of "tank waste treatment by 2028 by increasing the capacity of the planned Waste Treatment Plant (WTP) and using supplemental technologies for waste treatment and immobilization." The plan identified specific technologies to be evaluated for supplemental treatment of as much as $55 \%$ to $70 \%$ of the low-activity waste (LAW). The objective was to complete required testing and evaluation that would "...bring an appropriate combination of the above technologies to deployment to supplement LAW treatment and immobilization in the WTP to achieve the completion of tank waste treatment by 2028."

The DOE Office of River Protection tank farm contractor, CH2M HILL Hanford Group, Inc. (CH2M HILL), was tasked with conducting and contracting with vendors to perform the required testing and evaluation needed to select the appropriate technologies for deployment (CH2M HILL 2003). Two of the supplemental technologies under consideration included Bulk Vitrification (BV) and Containerized Grout. ${ }^{\text {(a) }}$ Unlike the WTP LAW treatment, which applies vitrification within continuous-fed joule-heated ceramic melters, BV produces a glass waste form using batch melting within the disposal container. The containerized grout process applies an effective grout waste formulation to the LAW and places the cement-based product in a large container for solidification and disposal. The containerized grout process avoids large grout monoliths which facilitates retrieval if deemed necessary in the future.

The purpose of this study was to conduct a preliminary assessment of the likely performance of BV Glass and containerized grout waste forms and their ability to meet selected disposal performance objectives. ${ }^{\text {(b) }}$ The results of the preliminary assessment are intended to help bound the expected results of CH2M HILL-led testing and evaluation, provide early identification of potential issues and uncertainties that may require further evaluation, and provide initial data that may be used to support Environmental Impact Statement (EIS) ${ }^{(\mathrm{c})}$ analyses of supplemental treatment options. The study relies solely on previously documented information and engineering judgment, and is not intended to provide definitive information for technology selection or regulatory decisions.

(a) A third technology, Steam Reforming, is also being considered. This report only discusses the BV and containerized grout waste forms.

(b) This analysis was originally prepared as part of an internal DOE programmatic study. The results of this study are presented in this paper with permission from DOE Office of River Protection.

(c) The DOE issued a Notice of Intent in the Federal Register on January 8, 2003 to prepare an EIS for Retrieval, Treatment, and Disposal of Tank Waste and Closure of Single-Shell Tanks at the Hanford Site, Richland WA (68 FR 1052) 
The following assumptions were used to establish a basis for the preliminary assessment:

1. The total Na inventory in the LAW fraction of the tank waste to be treated is assumed to be 47,700 metric tons (MT) Na. ${ }^{(a)}$ The WTP Pretreatment Plant processes are expected to add an additional 9,000 MT Na from high-level waste (HLW) caustic washing and 2500 MT Na from neutralization of process streams. Therefore, the total mass of LAW Na to be immobilized is assumed to be 59,200 MT $(47,700+9,000+2500)$.

2. Three hypothetical cases were selected for this study representing combinations of processing through WTP LAW melters, BV, and containerized grout. Table 1.1 summarizes the split in percentage and MT Na between the three processing technologies and waste forms. These cases were not intended to represent specific options being considered, but were selected to provide upper and lower bounds for this preliminary assessment. An all WTP glass case was not evaluated because the Immobilized Low-Activity Waste Performance Assessment (Mann et al. 2001) addressed the expected performance of a WTP glass waste form with regard to disposal performance objectives.

Table 1.1. Immobilized LAW Cases Evaluated

\begin{tabular}{||c|c|c|c||}
\hline \multirow{2}{*}{ Bounding Case } & \multicolumn{2}{|c||}{ Immobilized LAW Na, \% of Total (MT Na) } \\
\cline { 2 - 4 } & $\begin{array}{c}\text { WTP LAW Melter } \\
\text { Glass }\end{array}$ & BV Glass & $\begin{array}{c}\text { Containerized } \\
\text { Grout }\end{array}$ \\
\hline All-Glass & $23 \%(13,600)$ & $77 \%(45,600)$ & -- \\
\hline All-Grout & - & -- & $100 \%(59,200)$ \\
\hline Combined Glass and Grout & $23 \%(13,600)$ & $47 \%(27,800)$ & $30 \%(17,800)$ \\
\hline
\end{tabular}

(a) The tank data used to estimate the total quantity of Na to be treated was compiled from the December 10, 2002 Best Basis Inventory (BBI) Summary Data for All Tanks; the December 10, 2002 BBI Calculation Detail for All Tanks; and the December 10, 2002 BBI Calculation Detail - Supplemental Analytes for All Tanks. These values are the best representation available of the Total Tank Inventory. BBI information is available on the Hanford Tanks Waste Information Network System (TWINS) website at http://twins.pnl.gov/twins3/twins.htm. 


\subsection{Disposal System Performance Objectives}

The primary regulatory requirements for a low-level waste (LLW) disposal system are defined in DOE Order 435.1, "Radioactive Waste Management" and its accompanying guides and manuals (DOE 2001a, DOE 2001b). In addition to the requirements explicitly noted in DOE Order 435.1, Washington State and Federal requirements (e.g., WAC 173-200-040 and 173-303-645) contain specific performance objectives and requirements governing disposal and protection of groundwater resources that must also be addressed (WAC 1990, WAC 2000). ${ }^{\text {(a) }}$ Table 2.1 summarizes the key performance objectives and performance assessment (PA) requirements ${ }^{(\mathrm{b})}$ deemed important to establishing initial PA results for the LAW treatment scenarios evaluated in this document.

Table 2.1. Disposal System Key Performance Objectives and Performance Assessment Requirements

\begin{tabular}{|c|c|c|c|}
\hline & Primary $^{(\mathfrak{c})}$ & \multicolumn{2}{|c|}{ Secondary Considerations } \\
\hline \multicolumn{4}{|c|}{ Performance Objective } \\
\hline $\begin{array}{l}\text { Radiological } \\
\text { dose to public }\end{array}$ & $\begin{array}{l}25 \mathrm{mrem} / \mathrm{yr} \text { all exposure } \\
\text { pathways dose to affected } \\
\text { public (DOE M 435.1) }\end{array}$ & $\begin{array}{l}4 \text { mrem/yr beta/photon } \\
\text { drinking water dose (40 CFR } \\
141 \text { and WAC 173-303-645) }\end{array}$ & $\begin{array}{l}\text { PA shall include an assessment of } \\
\text { impacts to water resources for purposes } \\
\text { of establishing limits on radionuclides } \\
\text { that may be disposed of near-surface } \\
\text { (DOE M 435.1 Appendix A) }\end{array}$ \\
\hline $\begin{array}{l}\text { Groundwater } \\
\text { resource } \\
\text { protection }\end{array}$ & & $\begin{array}{l}10 \mathrm{mg} / \mathrm{L} \text { Nitrate+Nitrite as } \mathrm{N} \\
\text { groundwater concentration }\end{array}$ & $\begin{array}{l}\text { Drinking water standard from } \\
\text { WAC } 173-200-040 \text { requirements for } \\
\text { groundwater resource protection }\end{array}$ \\
\hline \multicolumn{4}{|c|}{ Performance Assessment Requirements } \\
\hline \begin{tabular}{|l|} 
Time of \\
Compliance
\end{tabular} & 1000 years (DOE M 435.1) & $\begin{array}{l}\text { longer times }(>1000 \text { years, } \\
\text { e.g., } 10,000 \text { years) and/or time } \\
\text { of maxima } \\
\text { concentrations/dose } \\
\text { (DOE M 435.1) }\end{array}$ & $\begin{array}{l}\text { Longer times and maxima part of DOE- } \\
\text { required sensitivity/ uncertainty } \\
\text { analysis (DOE M 435.1 Appendix A) }\end{array}$ \\
\hline $\begin{array}{l}\text { Point of } \\
\text { Compliance }\end{array}$ & $\begin{array}{l}>100 \text { meter buffer beyond } \\
\text { disposal site (DOE M 435.1) }\end{array}$ & & \\
\hline Barriers & & & $\begin{array}{l}\text { PA shall address reasonably foreseeable } \\
\text { natural processes that might disrupt } \\
\text { barriers (DOE M 435.1 Appendix A) }\end{array}$ \\
\hline
\end{tabular}

(a) Additional treatment requirements for Hanford tank waste to meet the Land Disposal Restrictions under the Resource Conservation and Recovery Act are provided in Chapter 173-303 of the Washington Administrative Code (WAC).

(b) Performance objectives for the DOE-approved Hanford Immobilized Low-Activity Waste Performance Assessment: 2001 Version (Mann et al. 2001) are given in Performance Objectives for the Hanford Immobilized Low-Activity Waste (ILAW) Performance Assessment, HNF-EP-0826, Rev. 3. August 1999.

(c) Primary considerations represent explicit DOE-mandated performance objectives or requirements that must be applied in a radiological performance assessment. Secondary considerations represent additional DOE, federal, or state requirements or objectives that need to be considered within the performance assessment to support the conclusions, or to support disposal system permitting activities. 
A summary of the key performance objectives and PA requirements include:

- Dose to representative member of public shall not exceed $25 \mathrm{mrem} / \mathrm{yr}$, all exposure pathways. DOE M 435.1-1, Section IV.P.1.a

- The PA shall include calculations for a 1,000 year period after closure for potential doses and releases. DOE M 435.1-1, Section IV.P.2.

- Point of compliance shall correspond to the point of highest projected dose or concentration beyond a 100 meter buffer zone surrounding the disposed waste. DOE M 435.1-1, Section IV.P.2.b (Note: a larger or smaller buffer zone may be used if adequate justification is provided).

- The PA shall include a sensitivity/uncertainty analysis. DOE M 435.1-1, Section IV.P.2.e (Note: DOE M 435.1-1, Appendix A further clarifies that "In addition to calculations over the time of compliance (1000 years), PAs also are to present calculations of the maxima relative to each of the performance objectives. The results of these calculations are to be part of the sensitivity and uncertainty analysis which would support a conclusion that the model is providing a reasonable projection. These longer calculations address the need to ensure that there are no unexpected significant increases shortly after the time of compliance ..." However, "The significance of these results (that exceed the performance objectives) must be handled with caution...")

- The PA shall address reasonably foreseeable natural processes that might disrupt barriers against release and transport of radioactive materials. DOE M 435.1-1, Section IV.P.2.c. (Note:

DOE M 435.1-1 Appendix A further clarifies that “.... barrier cannot necessarily be modeled as if it continues to function over long periods as it does at the time of construction......modelers have to account for the possibility of aggradation or degradation of the cover systems, degradation of concrete, consolidation of waste materials, etc." Also, M 435.1-1 also clarifies that use of "....any hypothetical extreme events that may or may not occur would result in overly conservative results.")

- For purposes of establishing limits on radionuclides that may be disposed of near-surface, the PA shall include an assessment of impacts to water resources. DOE M 435.1-1, Section IV.P.2.g (Note: DOE M 435.1-1 Appendix A further clarifies that "this requirement addresses the weakness and condition of eventual degradation of the disposal facility to the point where water resources around the disposal facility could be impacted, leading to health effects long in the future..." "At some disposal facilities, the performance measure selected to protect groundwater will be $4 \mathrm{mrem} / \mathrm{yr}$ through the drinking water pathway..." (i.e., application of the federal safe drinking water act, 40 CFR 141). 


\subsection{Initial Performance Assessment Results}

\subsection{Background}

Immobilized low-activity waste (ILAW) disposal PA analyses have been conducted several times for Hanford tank waste disposal. A PA was conducted for disposal of grouted double-shell tank (DST) wastes and documented in 1995 (Kincaid et al. 1995). Two PAs for vitrified LAW were documented; the first in 1998 (Mann et al. 1998) and the second in 2001 (Mann et al. 2001). These prior PAs provide a foundation for estimating potential PA results for alternate LAW forms and disposal systems. The Savannah River Site (SRS) PA for Saltstone (Cook and Fowler, 1992) also provides valuable information to help bound potential performance of a grouted waste form for Hanford.

\subsection{Assumptions}

The primary assumptions for the initial PA estimates include:

- The base case scenario within the 2001 ILAW PA (Mann et al. 2001) provides the foundation for performance comparisons of All-Glass, All-Grout, and a Combined Glass/Grout LAW combination option within this report. This base case scenario assumes:

a. a glass waste form comprised of $100 \%$ WTP LAW melter glass is disposed in 200 East Area

b. only $20 \%$ of the expected ${ }^{99} \mathrm{Tc}$ inventory (5,790 of 28,900 curies total) and $22 \%$ of the ${ }^{129} \mathrm{I}$ inventory ( 22 of 101 curies total) is assumed to reside in the ILAW glass

c. surface barrier is a modified Resource Conservation and Recovery Act-compliant Subtitle C cap, but is assumed to fail immediately after installation. ${ }^{\text {(a) }}$ An infiltration rate of $4.2 \mathrm{~mm} / \mathrm{yr}$ used for this base analysis case corresponds to the rate measured for Hanford's natural Burbank loamy sand.

d. no subsurface sand-gravel capillary barrier is used

e. a resident farmer scenario for dose calculations

- The mechanisms of vadose zone and groundwater transport, and receptor pathway and dose is unaffected by the selection of the waste form.

- The potential impact of various assumption changes can be found or extrapolated from the extensive sensitivity analysis conducted and documented in the 2001 ILAW PA (Mann et al. 2001).

(a) Based on sensitivity analysis (Mann et al. 2001, Table 4-13), there is no significant difference in results if the barrier fails shortly after installation, or fails 500 years after installation. 
- The key radiological contaminants of concern impacting the PA are ${ }^{99} \mathrm{Tc}$ and ${ }^{129} \mathrm{I} .{ }^{(a)}$ Nitrate and nitrite are the key chemical contaminants of concern for a grout waste form (Kincaid et al. 1995; Cook and Fowler 1992). For this reason, this analysis has focused on three key contaminants of concern: Tc, I, and the sum of nitrate plus nitrite (as N).

\subsection{Methodology}

The methods and data used to estimate performance for the various LAW treatment and disposal options considered in this report are summarized below.

- To achieve the primary performance objectives required by DOE Order 435.1 and summarized in Section 2, the 2001 ILAW PA was used to identify the key contaminant-specific release rate limits that would ensure an all-pathways dose of less than $25 \mathrm{mrem} / \mathrm{yr}, 100$ meters downgradient of the disposal site. The release rate limits are inventory normalized, and calculated as parts per million per year. These release rate limits were adjusted from the 2001 ILAW PA base analysis case by a factor of $1 / 5$ to account for five times greater Tc (100\% vs. $20 \%)$ potentially being disposed as ILAW, corresponding to the estimated total Tc tank inventory of $28,900 \mathrm{Ci} .{ }^{\text {(b) }}$ This value is certainly larger than the actual Hanford tank waste inventory because the 2001 analysis included 3,000 to 6,000 curies of Tc recently determined to have previously been shipped off-site. Release rate limits are estimated at both 1,000 and 10,000 years to address both the DOE time of compliance and a longer time that more adequately represents the maxima cases. See Table 3.1 for the estimated release rate limits.

- Contaminant-specific release rates for each waste form were estimated based on available referenceable information and engineering judgment. A range of release rates was identified. Low and high release rates were estimated for each waste form and key contaminant (Table 3.2). The basis for the range and for a most probable rate is described in Section 3.4. Release rates are inventory normalized, and calculated as $\mathrm{ppm} / \mathrm{yr}$.

- For each LAW option case evaluated, a contaminant-specific total effective release rate was calculated by summing the product of the fraction of contaminant inventory and the contaminant and waste form-specific release rates, or:

(a) The all-pathways dose from ${ }^{99} \mathrm{Tc}$ and ${ }^{129} \mathrm{I}$ combined makes up $100 \%$ and $53 \%$ of the dose at 1,000 and 10,000 years, respectively. ${ }^{99} \mathrm{Tc}$ and ${ }^{129} \mathrm{I}$ combined contribute $100 \%$ of the beta/photon drinking water dose at both times - from Mann et al. 2001, Tables 4-4 and 4-5,

(b) Mann et al. 2001, Table 3-1. 
Table 3.1. Estimated Release Rate Limits for Key Contaminants to Achieve Radiological Dose and Groundwater Resource Protection Performance Objectives

\begin{tabular}{|c|c|c|c|c|c|}
\hline \multirow[b]{2}{*}{$\begin{array}{l}\text { Time } \\
\text { (Yr) }\end{array}$} & \multirow{2}{*}{$\begin{array}{l}\text { Radiological Dose } \\
\text { Performance } \\
\text { Objective }\end{array}$} & \multicolumn{3}{|c|}{$\begin{array}{c}\text { Inventory-Normalized Contaminant Release Rate } \\
\text { Limits (ppm/yr) }\end{array}$} & \multirow[b]{2}{*}{ Basis } \\
\hline & & ${ }^{99} \mathrm{Tc}^{(\mathrm{a})}$ & ${ }^{129} \mathbf{I}$ & $\begin{array}{l}\mathrm{NO}_{3}^{-}+\mathrm{NO}_{2}^{-} \\
\quad(\text { as } \mathrm{N})\end{array}$ & \\
\hline \multirow{2}{*}{$1,000^{(\mathrm{b})}$} & $\begin{array}{l}25 \mathrm{mrem} / \mathrm{yr} \text { all- } \\
\text { pathways }\end{array}$ & $<7.2 \mathrm{E}+04$ & $<1.8 \mathrm{E}+05$ & \multirow{2}{*}{$<4.4 \mathrm{E}+04$} & \multirow{4}{*}{$\begin{array}{l}\text { Calculated using } \\
\text { 2001 ILAW PA } \\
\text { data (Tables 4-1, } \\
4-5,4-8, \text { and 7-6) } \\
\text { and equations } \\
\text { (page 7-19) }\end{array}$} \\
\hline & $\begin{array}{l}4 \mathrm{mrem} / \mathrm{yr} \\
\text { beta/photon }\end{array}$ & $<5.2 \mathrm{E}+04$ & $<7.3 \mathrm{E}+05$ & & \\
\hline \multirow{2}{*}{10,000} & $\begin{array}{l}25 \mathrm{mrem} / \mathrm{yr} \text { all- } \\
\text { pathways }\end{array}$ & $<153$ & $<400$ & \multirow{2}{*}{$<93$} & \\
\hline & $\begin{array}{l}4 \mathrm{mrem} / \mathrm{yr} \\
\text { beta/photon }\end{array}$ & $<110$ & $<162$ & & \\
\hline
\end{tabular}

(a) Tc release rate limits calculated from the 2001 ILAW PA base analysis case were divided by 5 to account for the total (100\%) estimated Tc inventory to be immobilized.

(b) Due to long travel times ( $>5000$ years) through the vadose zone underlying the disposal facility, large contaminant release rates can occur without exceeding the dose performance objective during the 1,000 year time of compliance. The 10,000-year release rate limits more accurately reflect the rates required to ensure that the all-pathways dose performance objective is not exceeded at longer times after contaminants have migrated to the groundwater.

$$
\mathrm{R}_{\mathrm{i}}{ }^{\text {case n }}=\sum_{\mathrm{z}=1-3}\left(\mathrm{I}_{\mathrm{i}}{ }^{\text {waste form z }} / \mathrm{I}_{\mathrm{i}}{ }^{\text {Total }}\right) \mathrm{R}_{\mathrm{i}}{ }^{\text {waste form z }}
$$

where $\quad \mathrm{i}=$ key contaminant (where $\mathrm{i}$ is $\mathrm{Tc}, \mathrm{I}$, or nitrate + nitrite)

$\mathrm{n}=$ treatment bounding case number, where $\mathrm{n}=1,2,3$

$\mathrm{z}$ = waste form, where $\mathrm{z}=1$ (ILAW glass), 2 (BV Glass), 3 (Containerized Grout)

$\mathrm{R}_{\mathrm{i}}^{\text {case n }} \quad=$ total effective release rate ( $\mathrm{ppm} / \mathrm{yr}$ ) for contaminant "i" from all ILAW forms produced from case \#n

$\mathrm{R}_{\mathrm{i}}$ waste form $\mathrm{z}=$ waste form $\mathrm{z}$ release rate $(\mathrm{ppm} / \mathrm{yr}$ ) for contaminant " $\mathrm{i}$ " (from Table 3.2)

$\mathrm{I}_{\mathrm{i}}^{\text {waste form } \mathrm{z}}=$ total inventory $(\mathrm{Ci})$ of contaminant " $\mathrm{i}$ " to be immobilized in waste form $\mathrm{z}$

$\mathrm{I}_{\mathrm{i}}^{\text {Total }}=$ total inventory $(\mathrm{Ci})$ of contaminant " $\mathrm{i}$ " to be immobilized in all waste forms 


\subsection{Waste Form Release Rates}

Estimates of dose impacts from the PA strongly depend on the waste form release, and the waste form release dominates the time structure of the problem. ${ }^{(a)}$ This section describes the basis for the release rate estimates (Table 3.2) used in this analysis for the LAW Glass waste form expected from the WTP LAW melters, the glass waste form expected from a BV process, and the grout waste form expected from a containerized grout process.

\subsubsection{Glass from WTP LAW Melters}

The waste release mechanisms and rates for WTP LAW glasses used for the base analysis case in the 2001 ILAW PA was well documented within the PA and in supporting documents (Mann et al. 2001 and Bacon and McGrail 2001). The mechanisms for waste release from a glass matrix are driven by dissolution of the glass matrix. This mechanisms means that for glasses, the primary release rates are not contaminant-specific. As the glass surface dissolves in water, essentially all contaminants are released at the same rate from the waste form. Two glass formulations were used as reference points in the PA - the LAWABP1 glass used in the base analysis case, and the HLP-31 glass used in the sensitivity analysis to evaluate a higher waste loading glass. The rate at which these glasses dissolve is dependent on many variables, and can be predicted using computer simulations developed from extensive literature and research on the mechanisms of glass dissolution. This rate expression was used in conjunction with a reactive transport model for the 2001 ILAW PA to calculate an inventory-normalized contaminant flux (i.e., release rate) to the vadose zone in $\mathrm{ppm} / \mathrm{yr}$ as a function of time. For purposes of this analysis, these documented release rates for LAW Glass are shown in Table 3.2 and were used to bound the range of expected release rates.

A most probable release rate for LAW Glass was also selected. Because of the extensive testing conducted on the LAWABP1 glass in support of the PA and the extensive testing of the reference glass composition to be supplied by the WTP, there is reasonably high confidence that the future product from the LAW melters could achieve the release rates measured for this reference glass. Therefore, the most probable release rates for LAW Glass correspond to the low values of $0.12 \mathrm{ppm} / \mathrm{yr}$ and $.71 \mathrm{ppm} / \mathrm{yr}$ for 1,000 years and 10,000 years, respectively.

\subsubsection{Glass from BV}

The BV Glass has not been evaluated for Hanford LAW tank waste application to the extent the LAW Glasses have. BV-like glasses have been produced and tested for other waste applications, including significant testing on soil vitrification at Hanford during the 1980's and 1990's. However, testing methods for long-term glass performance that were used to support the ILAW PA have advanced significantly since 1990, and these new tests have not yet been applied to BV Glasses. However, the formulations for some of the LAW Glasses that have been tested are not significantly different from the

(a) From Mann et al. 2001, Page 4-35, section 4.5.1. 
formulations of BV Glasses. ${ }^{\text {(a) }}$ The most significant difference is that BV Glasses have a higher $\mathrm{NaO}$ waste loading (nominally $20 \mathrm{wt} \%$ vs. $14 \mathrm{wt} \%$ ) and are processed at higher temperature.

For this analysis, the assumption was made that waste release from BV Glass is driven by the glass dissolution mechanisms, and the waste form is expected to perform comparably to the LAW Glass. Therefore, the estimated range of release rates shown in Table 3.2 for the BV product are essentially identical to those for the WTP LAW melter product. The basis for this assumption and other BV factors that may affect waste form performance include:

- The BV process can operate at higher temperatures than the WTP LAW melters.

- $\mathrm{BV}$ is expected to obtain higher waste loading than that of the LAWABP1 reference LAW Glasses involving significant amounts of sulfur. BV Glasses are not expected to be sulfur limited.

- Thermal gradients within the container during BV melting are expected to produce significant mixing based on modeling and prior testing. However, unlike glass produced in melters, the batch process has a greater potential to produce a product with more heterogeneity throughout the waste container.

- Because of the container size and shape, cooling of the glass after BV melting is likely to be less controlled than for WTP-produced glass.

- Extensive glass formulation development work has been performed and documented for LAW Glasses, whereas less comparable formulation development work has been performed for BV Glasses.

The current lack of data on BV Glasses produced from Hanford LAW simulated or actual wastes significantly increases the uncertainty of BV Glass performance. Therefore, the most probable release rates are assumed to be approximately $10 \mathrm{X}$ the most probable release rates for LAW Glasses. The most probable release rates for BV Glass are estimated at $1 \mathrm{ppm} / \mathrm{yr}$ and $7 \mathrm{ppm} / \mathrm{yr}$ for 1,000 years and 10,000 years, respectively.

\subsubsection{Containerized Grout}

The waste release mechanisms from grout waste forms are assumed to be driven by diffusion. Unlike glass, where the contaminants are incorporated chemically within the glass matrix and surface matrix dissolution causes the release, contaminants within the grout matrix are generally believed to be physically encapsulated. Therefore, contaminants will diffuse out of the grout matrix toward the grout package surface where infiltration water carries the contaminant away from the disposal site. Diffusion rates are contaminant specific. Release rates can be calculated using a similar approach to that used in the 2001 ILAW PA. However, instead of using a reactive transport model to incorporate the glass dissolution

(a) The low-activity waste glass formulations, whether LAW Glass from WTP or BV Glass, all contain various compositions of Na, B, Al, and Si. Depending on the formulations selected for specific waste feeds, both glasses can be referred to as borosilicate, sodium borosilicate, sodium aluminosilicate, and aluminosilicate. 
reaction rate expression, a transport model using molecular diffusion expressions can be used.

Contaminant-specific diffusion coefficients are calculated from grout leaching test results and used in the transport models to predict the flux or rate of release of contaminants from the disposal system to the vadose zone.

Neither diffusion coefficients nor release rates have been determined for containerized grout formulations for Hanford LAW. Waste release from grouts was tested and modeled extensively in both the SRS Saltstone PA and the previous Hanford grout PA. Unfortunately, each of these PAs assumed large grout monoliths in vaults rather than grout containers in a trench. Therefore, these past PAs cannot be directly applied to the current grout option.

To estimate release rates for the containerized grout option, the following assumptions were made and approach taken:

- Diffusion coefficients for Tc and nitrate could be directly obtained or back calculated from results of the Saltstone and Hanford grout PAs to bound the range of likely diffusion coefficients that would be obtained with containerized grout formulations.

- The iodine diffusion coefficient is expected to be comparable to that of Tc.

- A simple analytic release expression for diffusion-dominated transport is adequate to estimate the inventory-normalized contaminant flux out of a disposal package for this analysis. ${ }^{(a)}$

- The contaminant-specific release rates were calculated at 1,000 and 10,000 years for Tc and I, and nitrate + nitrite, and are shown in Table 3.2.

To estimate most probable release rates for containerized grout, differences in grout formulation and processing baseline assumptions for the original Hanford grout treatment facility and the existing SRS Saltstone processing facility were considered. Key differences include:

- The SRS saltstone diffusion coefficient for Tc is approximately 5 orders of magnitude less than that used for the compliance case within the original Hanford grout PA $\left(2.5 \mathrm{E}-12 \mathrm{vs} .2 \mathrm{E}-07 \mathrm{~cm}^{2} / \mathrm{sec}\right){ }^{(b)}$ Saltstone is formulated to chemically reduce Tc and lower the diffusion coefficient. Therefore, Saltstone is assumed to provide a reasonable lower range of possible diffusion coefficients.

- Hanford grout program test results with tank waste confirmed the higher diffusion coefficient for Tc for the majority of grout formulations and tank wastes tested. However, at least one tank waste type

(a) The simplified flux calculation used equations previously applied in the Waste Isolation Pilot Plant Disposal Phase Draft Supplemental Environmental Impact Statement. DOE/EIS-0026-5-2. November 1996.

(b) Diffusion coefficients are not directly available from the SRS Saltstone PA. Diffusion coefficients were back calculated from Kd values using the method documented in the Hanford grout PA (Kincaid et al. 1995; Pages 3.35-3.37). Kds for saltstone were taken from the SRS Saltstone PA (Cook and Fowler, 1992; Page D-2 for Tc; Page A-12 for Nitrate). Diffusion coefficients for Hanford grout are taken from the Hanford grout PA, Page 3.37 for Tc and page 3.36 for Nitrate. 
and corresponding grout formulation had a measured Tc diffusion coefficient close to that of the SRS Saltstone value.

- Higher water to cement ratios were used in many of the Hanford grout formulations than in the SRS Saltstone formulation. This may be attributed to a difference in design requirements and a pumping constraint that may contribute to differences in grout formulation and performance. This design requirement and constraint is not likely to be required for a containerized grout process.

- Data indicates that the performance of some Hanford grouts may have been impacted by curing at elevated temperatures (e.g., $85-95^{\circ} \mathrm{C}$ ). Containerized grout, with its smaller disposal package volume and lower Cs loadings than originally planned for the Hanford grout program, is not likely to experience higher temperature curing.

Based on this preliminary comparison of the Hanford grout and SRS Saltstone PAs, it appears that significantly lower diffusion coefficients than those measured and used in the original Hanford grout compliance case may be possible. A combination of formulation enhancements, tanks wastes selected for grouting, curing temperature, water to cement ratios, and other factors could contribute to significantly lower release rates than previously estimated for Hanford grout. However, the lack of simulated or actual waste form test results to verify containerized grout performance increases the uncertainty.

The most probable release rate for Tc and I is assumed to be $100 \mathrm{ppm} / \mathrm{yr}$ for both 1,000 and 10,000 years. One order of magnitude improvement over previously measured values for Hanford grouts is very probable for the 1,000 year value. The range of estimated release rates for nitrate+nitrite is not as wide as Tc, and there is a low likelihood that order of magnitude improvements could be made. Therefore, the most probable release rates for nitrate+nitrite is estimated to be $500 \mathrm{ppm} / \mathrm{yr}$ and $200 \mathrm{ppm} / \mathrm{yr}$ for 1,000 and 10,000 years, respectively.

\subsection{Results and Discussion}

The total effective release rate estimates (i.e., $\mathrm{R}_{\mathrm{i}}^{\text {case } \mathrm{n}}$, from Section 3.3) for the All-Grout, All-Glass, and Combined Glass/Grout cases are presented in Table 3.3 for 1,000 and 10,000 years. The estimates use the most probable waste form- and contaminant-specific release rates described earlier. For this study, the total inventory of ${ }^{99} \mathrm{Tc}(28,900$ curies $)$ is assumed to distribute proportionally with the sodium across the glass and grout waste forms. Similarly, the total inventory of ${ }^{129} \mathrm{I}$ is assumed to distribute proportionally with the sodium. However, consistent with the ILAW PA assumption, only $22 \%$ of the ${ }^{129}$ I processed through vitrification is assumed to be retained in the LAW Glass or BV Glass products. The balance of the ${ }^{129} \mathrm{I}$ is assumed to volatilize during vitrification. It is assumed that all of the ${ }^{129} \mathrm{I}$ processed through containerized grout is retained in the grout waste form.

For the 1,000 year time of compliance, all three cases result in total effective release rates well below the limits required to ensure that the $25 \mathrm{mrem} / \mathrm{yr}$ performance objective and $10 \mathrm{mg} / \mathrm{L}$ nitrate + nitrite (as N) drinking water limit is met during the compliance period. This result is not unexpected. Due to long travel times $(>5000 \text { years })^{(a)}$ through the vadose zone underlying the disposal facility, large contaminant

(a) Mann et al. 2001, Table 4-13, Base Analysis Case. 
Table 3.3. Estimated Total Effective Release Rates for Key Contaminants (using most probable waste form-specific release rates)

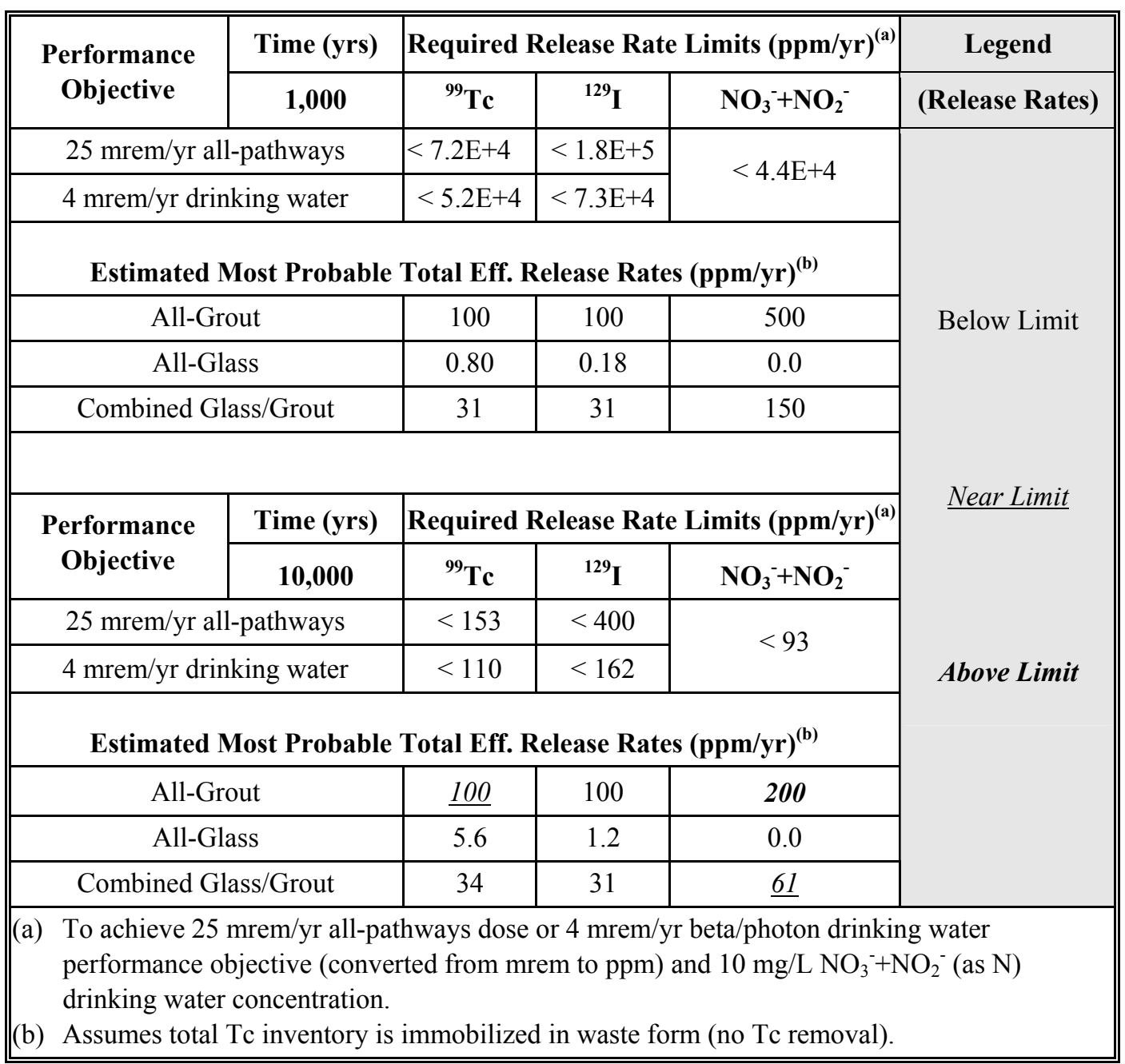

release rates can occur without exceeding the performance objectives during the 1,000 year time of compliance. However, assessment of longer times is required by DOE Order 435.1-1 for purposes of identifying maxima and evaluating the sensitivity of the assessment.

At 10,000 years, the All-Grout case is estimated to exceed release rate limits for nitrate + nitrite by greater than $2 \mathrm{X}$, and the total effective release rate for Tc is approaching the limit (i.e., $67 \%$ and $90 \%$ of the release rate limits for the $25 \mathrm{mrem} / \mathrm{yr}$ and $4 \mathrm{mrem} / \mathrm{yr}$ performance objectives, respectively). The Combined Glass/Grout case is estimated to produce total effective release rates below the 10,000 year limits. However, Tc and nitrate + nitrite estimates are at $23 \%$ and $68 \%$ of the $25 \mathrm{mrem} / \mathrm{yr}$ and $10 \mathrm{mg} / \mathrm{L}$ performance objectives, respectively. Only the All-Glass case provides total effective release rates for all key contaminants an order of magnitude or more below the release limits at 10,000 years for all performance objectives. 
Comparing the results for the most probable release rates (Table 3.3) with the high and low values of each release rate (Tables 3.4 and 3.5) provides additional insight.

- If the high range values of the waste form-specific release rates were realized, the All-Grout and Combined Glass/Grout scenarios are estimated to exceed performance objectives at 10,000 years. The All-Grout scenario exceeds the Tc release limit for the $25 \mathrm{mrem} / \mathrm{yr}$ performance objective and greatly exceeds the nitrate + nitrite release limit. The Combined Glass/Grout case slightly exceeds the Tc release limit for the $4 \mathrm{mrem} / \mathrm{yr}$ performance objective and the nitrate + nitrite release limit by approximately $2 \mathrm{X}$.

- The All-Grout case will very likely require additional mitigating actions to avoid exceeding performance objectives at longer-times, especially for Tc. A Monte Carlo Analysis of the probability distributions for total effective release rates for Tc at the 10,000-year time frame was

Table 3.4. Estimated Total Effective Release Rates for Key Contaminants (using high range for waste form-specific release rates)

\begin{tabular}{|c|c|c|c|c|c|}
\hline \multirow{2}{*}{$\begin{array}{c}\text { Performance } \\
\text { Objective }\end{array}$} & \multirow{2}{*}{$\begin{array}{c}\text { Time (yrs) } \\
1,000\end{array}$} & \multicolumn{3}{|c|}{ Required Release Rate Limits (ppm/yr) ${ }^{(\mathrm{a})}$} & \multirow{2}{*}{$\begin{array}{c}\text { Legend } \\
\text { (Release Rates) }\end{array}$} \\
\hline & & ${ }^{99} \mathrm{Tc}$ & ${ }^{129} \mathbf{I}$ & $\mathrm{NO}_{3}^{-}+\mathrm{NO}_{2}^{-}$ & \\
\hline \multicolumn{2}{|c|}{$25 \mathrm{mrem} / \mathrm{yr}$ all-pathways } & $<7.2 \mathrm{E}+4$ & $<1.8 \mathrm{E}+5$ & \multirow{2}{*}{$<4.4 \mathrm{E}+4$} & \multirow{6}{*}{ Below Limit } \\
\hline $4 \mathrm{mrem} / \mathrm{yr}$ drir & king water & $<5.2 \mathrm{E}+4$ & $<7.3 \mathrm{E}+4$ & & \\
\hline \multicolumn{5}{|c|}{ Estimated High Range Total Eff. Release Rates (ppm/yr) ${ }^{(\mathbf{b})}$} & \\
\hline \multicolumn{2}{|c|}{ All-Grout } & 1000 & 1000 & 2000 & \\
\hline \multicolumn{2}{|c|}{ All-Glass } & 20 & 4.4 & 0.0 & \\
\hline \multicolumn{2}{|c|}{ Combined Glass/Grout } & 320 & 310 & 610 & \\
\hline & & & & & \multirow[t]{9}{*}{ Near Limit } \\
\hline \multirow{2}{*}{$\begin{array}{l}\text { Performance } \\
\text { Objective }\end{array}$} & Time (yrs) & \multicolumn{3}{|c|}{ Required Release Rate Limits (ppm/yr) ${ }^{(a)}$} & \\
\hline & 10,000 & ${ }^{99} \mathrm{Tc}$ & ${ }^{129} \mathrm{I}$ & $\mathrm{NO}_{3}^{-}+\mathrm{NO}_{2}^{-}$ & \\
\hline \multicolumn{2}{|c|}{$25 \mathrm{mrem} / \mathrm{yr}$ all-pathways } & $<153$ & $<400$ & \multirow{2}{*}{$<93$} & \\
\hline \multicolumn{2}{|c|}{$4 \mathrm{mrem} / \mathrm{yr}$ drinking water } & $<110$ & $<162$ & & \\
\hline \multicolumn{5}{|c|}{ 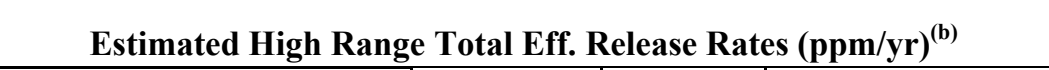 } & \\
\hline \multicolumn{2}{|c|}{ All-Grout } & 250 & 250 & 600 & \\
\hline \multicolumn{2}{|c|}{ All-Glass } & 51 & $\overline{11}$ & 0.0 & \\
\hline \multicolumn{2}{|c|}{ Combined Glass/Grout } & $\underline{110}$ & 84 & 180 & \\
\hline \multicolumn{6}{|c|}{$\begin{array}{l}\text { (a) To achieve } 25 \mathrm{mrem} / \mathrm{yr} \text { all-pathways dose or } 4 \mathrm{mrem} / \mathrm{yr} \text { beta/photon drinking water } \\
\text { performance objective and } 10 \mathrm{mg} / \mathrm{L} \mathrm{NO}_{3}^{-}+\mathrm{NO}_{2}^{-} \text {(as } \mathrm{N} \text { ) drinking water concentration. } \\
\text { (b) Assumes total Tc inventory is immobilized in waste form (no Tc removal). }\end{array}$} \\
\hline
\end{tabular}


Performed. ${ }^{(a)}$ Figure 3.1 presents the results of this analysis where the range of possible Tc release rates for containerized grout were varied randomly. This analysis forecasts a $72 \%$ chance that the All-Grout case will achieve a total effective release rate for Tc below the $153 \mathrm{ppm} / \mathrm{yr}$ release rate limit required to meet the $25 \mathrm{mrem} / \mathrm{yr}$ performance objective at 10,000 years (i.e., $28 \%$ chance that the Tc release limit will be exceeded). Mitigating actions for the All-Grout case may include:

$\circ$ Tc removal for all or some of the waste inventory

- Significant improvements to grout performance (e.g., Tc getters) or significant development and testing to provide a high degree of confidence in achieving the low-range release rates

- Additional surface or subsurface barrier technology to reduce infiltration rates, and

○ Relief or exemption for nitrate + nitrite drinking water standard performance objective

Table 3.5. Estimated Total Effective Release Rates for Key Contaminants (using low range for waste form-specific release rates)

\begin{tabular}{|c|c|c|c|c|c|}
\hline \multirow{2}{*}{$\begin{array}{l}\text { Performance } \\
\text { Objective }\end{array}$} & \multirow{2}{*}{$\begin{array}{c}\text { Time (yrs) } \\
1,000\end{array}$} & \multicolumn{3}{|c|}{ Required Release Rate Limits $(\mathrm{ppm} / \mathrm{yr})^{(\mathrm{a})}$} & \multirow{2}{*}{$\frac{\text { Legend }}{\text { (Release Rates) }}$} \\
\hline & & ${ }^{99} \mathrm{Tc}$ & ${ }^{129} \mathrm{I}$ & $\mathrm{NO}_{3}^{-}+\mathrm{NO}_{2}^{-}$ & \\
\hline \multicolumn{2}{|c|}{$25 \mathrm{mrem} / \mathrm{yr}$ all-pathways } & $<7.2 \mathrm{E}+4$ & $<1.8 \mathrm{E}+5$ & \multirow{2}{*}{$<4.4 \mathrm{E}+4$} & \multirow{14}{*}{ Below Limit } \\
\hline $4 \mathrm{mrem} / \mathrm{yr}$ driı & xing water & $<5.2 \mathrm{E}+4$ & $<7.3 \mathrm{E}+4$ & & \\
\hline Estimate & Low Range & Total Eff. R & ease Rates & $\mathbf{m} / \mathbf{y r})^{(\mathbf{b})}$ & \\
\hline All-Gr & & 3.0 & 3.0 & 130 & \\
\hline All-Gl & & 0.10 & 0.02 & 0.0 & \\
\hline Combined $\mathrm{G}$ & iss/Grout & 0.99 & 0.93 & 40 & \\
\hline \multirow{2}{*}{$\begin{array}{l}\text { Performance } \\
\text { Objective }\end{array}$} & Time (yrs) & \multicolumn{3}{|c|}{ Required Release Rate Limits (ppm/yr) ${ }^{(\mathrm{a})}$} & \\
\hline & $\mathbf{1 0 , 0 0 0}$ & ${ }^{99} \mathrm{Tc}$ & ${ }^{129} \mathrm{I}$ & $\mathrm{NO}_{3}^{-}+\mathrm{NO}_{2}^{-}$ & \\
\hline \multicolumn{2}{|c|}{$25 \mathrm{mrem} / \mathrm{yr}$ all-pathways } & $<153$ & $<400$ & \multirow{2}{*}{$<93$} & \\
\hline \multicolumn{2}{|c|}{$4 \mathrm{mrem} / \mathrm{yr}$ drinking water } & $<110$ & $<162$ & & \\
\hline \multicolumn{5}{|c|}{ Estimated Low Range Total Eff. Release Rates (ppm/yr) ${ }^{(\mathbf{b})}$} & \\
\hline \multicolumn{2}{|c|}{ All-Grout } & 1.0 & 1.0 & 40 & \\
\hline \multicolumn{2}{|c|}{ All-Glass } & 0.70 & 0.15 & 0.0 & \\
\hline \multicolumn{2}{|c|}{ Combined Glass/Grout } & 0.79 & 0.41 & 12 & \\
\hline \multicolumn{6}{|c|}{$\begin{array}{l}\text { (a) To achieve } 25 \mathrm{mrem} / \mathrm{yr} \text { all-pathways dose or } 4 \mathrm{mrem} / \mathrm{yr} \text { beta/photon drinking water } \\
\text { performance objective and } 10 \mathrm{mg} / \mathrm{L} \mathrm{NO}_{3}^{-}+\mathrm{NO}_{2}^{-} \text {(as } \mathrm{N} \text { ) drinking water concentration. } \\
\text { (b) Assumes total Tc inventory is immobilized in waste form (no Tc removal). }\end{array}$} \\
\hline
\end{tabular}

(a) To perform the Monte Carlo analysis, Crystal Ball 2000 Professional Edition (v5.0) by Decisioneering, Inc., was used. The range of expected Tc release rates from Table 3.2 for 10,000 years was used as input. 
Forecast: All Grout Case

72\% Chance that Total Effective Tc Release Rate is Less Than 153

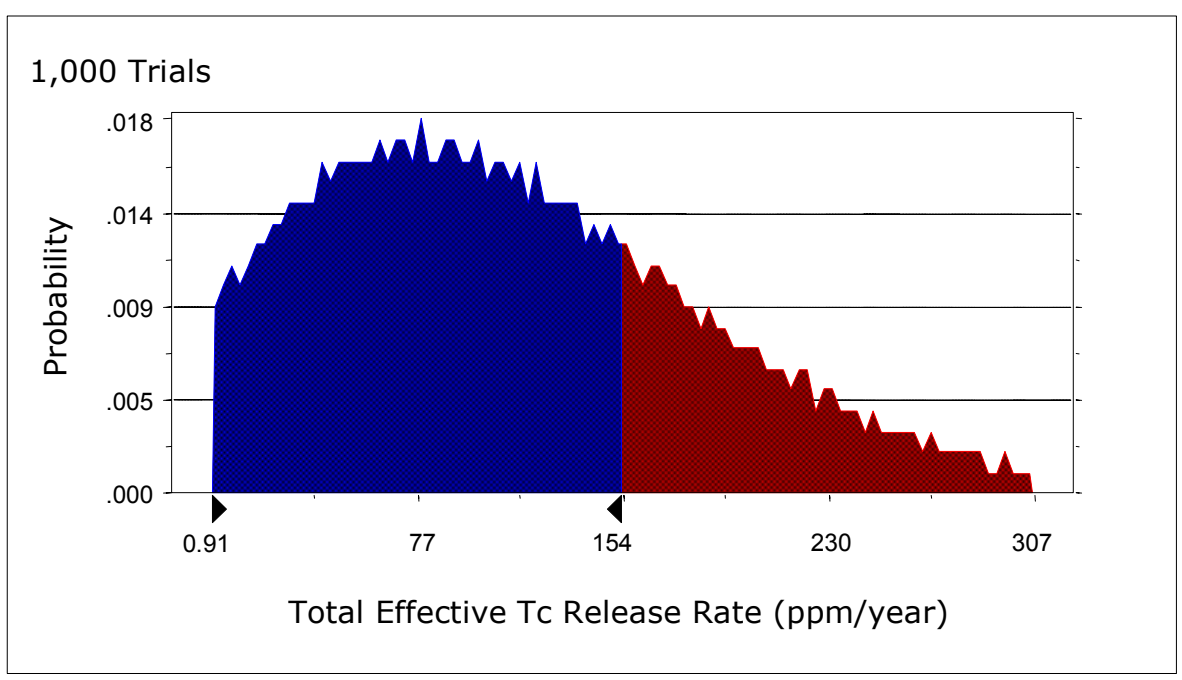

Figure 3.1. Results of Monte Carlo Analysis of Tc Release from the All-Grout Scenario at 10,000 Years

- The Combined Glass/Grout case may also require mitigating actions to ensure performance objectives at longer-times are not exceeded. Mitigating actions may include:

- Limiting the wastes to be treated by containerized grout to tanks with the lowest Tcconcentrations. For simplification, this assessment assumed an average and constant $\mathrm{Tc} / \mathrm{Na}$ ratio for all tanks.

- Confirming the release rates for each waste form, selecting tanks for each process (i.e., WTP Vitrification; BV; Containerized Grout) to minimize the release of key contaminants, and monitoring immobilized waste product quality.

○ Relief or exemption for nitrate+nitrite drinking water standard performance objective. 


\subsection{Summary and Conclusions}

Table 4.1 summarizes the discussion of treatment requirements contained in this report. Based on this assessment (and using the high range for waste form-specific release rates), additional treatment should not be required if glass is the sole waste form, regardless of whether WTP glass or BV glass is used. Similarly, additional treatment should not be required if a combination of grout and glass is used (wastes that would require additional treatment prior to grouting could be vitrified instead). However, if grout is the sole waste form for LAW, under both the most probable and high range for waste form-specific release rates, some treatment for RCRA regulated constituents ${ }^{(a)}$ and mitigating actions for $\mathrm{Tc}$ and $\mathrm{NO}_{3}+$ $\mathrm{NO}_{2}$ would likely be required in order to meet applicable requirements and gain necessary regulatory approvals for disposal.

Predictions looking thousands of years into the future are highly uncertain, and accordingly the estimating approaches tend to be conservative to compensate for this uncertainty. Depending upon the assumptions made regarding the effectiveness of barriers, release mechanisms, and transport properties, it is possible for any waste disposal form and facility to exceed groundwater standards established to provide conservative levels of protection for current generations.

The 2001 ILAW PA performed significant sensitivity analysis consistent with DOE requirements. It identified three key variables that could affect release rates: disposal site location; Tc removal; and addition of a subsurface capillary barrier to the disposal system. These variables may require more thorough consideration to determine their impact on release rates to support supplemental treatment technology evaluation, decisions, or regulatory permitting activities.

Table 4.1. Summary of Treatment Requirements

\begin{tabular}{||l|c|l|c||}
\hline \multirow{2}{*}{ Treatment Requirement } & \multicolumn{3}{|c||}{ Composition } \\
\cline { 2 - 4 } & All-Glass & Combined Grout/Glass & All-Grout \\
\hline Tc Mitigation & No & $\begin{array}{l}\text { Dependent on what } \\
\text { fraction is grouted vs. } \\
\text { fraction vitrified }\end{array}$ & Yes \\
\hline $\mathrm{NO}_{3}+\mathrm{NO}_{2}$ Mitigation & No & $\begin{array}{l}\text { Dependent on what } \\
\text { fraction is grouted vs. } \\
\text { fraction vitrified }\end{array}$ & Yes \\
\hline
\end{tabular}

(a) Pursuant to the RCRA land disposal restrictions applicable to tank waste, the treated waste forms must meet the Universal Treatment Standards (40 CFR 268.48). These standards address both organic compounds and metals as well as treatment technologies but do not address radionuclides. 


\subsection{References}

40 CFR 268. May 26, 1998. Land Disposal Restrictions, U.S. Environmental Protection Agency, Washington, D.C.,

68 FR 1052. January 8, 2003. Notice of Intent to Prepare an Environmental Impact Statement for Retrieval, Treatment, and Disposal of Tank Waste and Closure of Single-Shell Tanks at the Hanford Site, pp 1052-1057, January 8, 2003. U.S. Department of Energy, Richland, Washington.

Bacon, DH and BP McGrail. 2001. Waste Form Release Calculations for the 2001 Immobilized LowActivity Waste Performance Assessment. PNNL-13369. February 2001. Pacific Northwest National Laboratory, Richland, Washington.

CH2M HILL. 2003. Integrated Mission Acceleration Plan. RPP-13678, Revision 0. CH2M HILL Hanford Group, Inc. Richland, Washington.

Cook JR and JR Fowler. 1992. Radiological Performance Assessment for the Z-Area Saltstone Disposal Facility (U). WSRC-RP-92-1360 Rev 0. Westinghouse Savannah River Company. Aiken, South Carolina.

Kincaid CT, JW Shade, GA Whyatt, MG Piepho, K Rhoads, JA Voogd, JH Westsik, Jr., MD Freshley, KA Blanchard, and BG Lauzon. 1995. Performance Assessment of Grouted Double-Shell Tank Waste Disposal at Hanford. WHC-SD-WM-EE-004, Rev. 1, Vol. 1 \& 2, Westinghouse Hanford Company, Richland, Washington.

Mann FM, RJ Puigh, II, PD Rittman, NW Kline, JA Voogd, Y Chen, CR Eiholzer, CT Kincaid, BP McGrail, AH Lu, GF Williamson, NR Brown, and PE LaMont. 1998. Hanford Immobilized LowActivity Tank Waste Performance Assessment. DOE/RL-97-69, U.S. Department of Energy, Richland, Washington.

Mann, FM, DH Bacon DH, KC Burgard, SH Finfrock, EJ Freeman, R Khaleel, PR Lamont, BP McGrail, RJ Puigh, WR Root, and SK Wurstner. 2001. Hanford Immobilized Low-Activity Waste Performance Assessment: 2001 Version. DOE/ORP-2000-24, Revision 0. U.S. Department of Energy, Richland, Washington.

U.S. Department of Energy (DOE). 2001a. Radioactive Waste Management Manual, DOE M 435.1, Change 1, June 19, 2001. U.S. Department of Energy, Washington D.C.

U.S. Department of Energy (DOE). 2001b. Radioactive Waste Management, DOE Order 435.1, Change 1, August 28, 2001. U.S. Department of Energy, Washington D.C.

U.S. Department of Energy (DOE). 2002. Performance Management Plan for the Accelerated Cleanup of the Hanford Site. DOE/RL-2002-47, Revision D. U.S. Department of Energy, Richland, Washington. 
WAC 1990. Water Quality Standards for Groundwaters of the State of Washington, Washington Administrative Code, Chapter WAC 173-200. October 31,1990. Washington State Department of Ecology, Olympia, Washington.

WAC 2000. Dangerous Waste Regulations, Washington Administrative Code, Chapter 173-303. December 10, 2000. Washington State Department of Ecology, Olympia, Washington. 


\section{Distribution}

No. Of

Copies

(Onsite)

8 CH2M HILL Hanford Group
R.E. Raymond
H6-22
R.W. Powell (2)
H6-22
R. Ni
H6-03
G.W. McLellan
H9-01
M.N. Jarayssi
H6-03
D.I. Allen
H6-03
F. Mann
E6-35

3 DOE - Office of River Protection

B.M. Mauss H6-60

M.E. Burandt H6-60

W.F. Hamel H6-60

21 Pacific Northwest National Laboratory

T.M. Brouns (10) K9-69

P.A. Gauglitz K6-28

W.C. Weimer K9-09

J.W. Brothers K7-15

L.K. Holton H6-61

G.B. Mellinger H6-61

M.E. Lerchen K7-97

L.A. Bagaasen K6-28

R.J. Serne P8-37

L.R. Roeder K9-69

Information Release (2) K1-06 